\title{
John Dewey on Public Office and Representative Democracy
}

\author{
Pedersen, Kirstine Zinck
}

Document Version

Accepted author manuscript

Published in:

European Journal of Cultural and Political Sociology

DOI:

10.1080/23254823.2019.1690537

Publication date:

2020

License

Unspecified

Citation for published version (APA):

Pedersen, K. Z. (2020). John Dewey on Public Office and Representative Democracy. European Journal of Cultural and Political Sociology, 7(1), 75-95. https://doi.org/10.1080/23254823.2019.1690537

Link to publication in CBS Research Portal

\section{General rights}

Copyright and moral rights for the publications made accessible in the public portal are retained by the authors and/or other copyright owners and it is a condition of accessing publications that users recognise and abide by the legal requirements associated with these rights.

Take down policy

If you believe that this document breaches copyright please contact us (research.lib@cbs.dk) providing details, and we will remove access to the work immediately and investigate your claim. 


\title{
John Dewey on Public Office and Representative Democracy
}

\author{
Kirstine Zinck Pedersen
}

Journal article (Accepted manuscript*)

\section{Please cite this article as:}

Pedersen, K. Z. (20२०). John Dewey on Public Office and Representative Democracy. European Journal of Cultural and Political Sociology, 7(1), 75-95. https://doi.org/10.1080/23254823.2019.1690537

This is an Accepted Manuscript of an article published by Taylor \& Francis in European Journal of Cultural and Political Sociology on २० Nov 2019, available online:

DOI: http://www.tandfonline.com/10.1080/23254823.2019.1690537

* This version of the article has been accepted for publication and undergone full peer review but has not been through the copyediting, typesetting, pagination and proofreading process, which may lead to differences between this version and the publisher's final version AKA Version of Record.

Uploaded to CBS Research Portal: August २०२० 
John Dewey on public office and representative democracy

Kirstine Zinck Pedersen, PhD

Associate Professor

Department of Organization

Copenhagen Business School

Kilen, Kilevej 14A

DK-2000 Frederiksberg

Denmark

Mobil: +45 41852233

Email: kzp.ioa@.cbs.dk 


\begin{abstract}
Recent decades have seen rising interest in John Dewey's political philosophy, often in discussions of the presumed crisis of democracy, rising populism in Western political systems, or the triumph of neoliberalism. This paper presents a rare reading of Dewey as a theorist of office and political representation, where it is only meaningful to approach 'the public' as public offices organised through the state. In Dewey's understanding of democracy, public office is extended to the citizen, who must be educated to participate in public engagement and who has a duty to vote not as a private person but as a representative of the public interest. From this perspective, a democracy must be judged by the extent to which it is able to secure both its traditional public officers' and its citizens' representative functions, character, and conduct rather than by its ideas, for instance, of freedom of speech or public will.
\end{abstract}

Keywords: John Dewey, the public, public office, representative democracy, Thomas Hobbes, Walter Lippmann.

\title{
Acknowledgements:
}

This research was part of the Velux Foundation research project 'Office as a vocation'. I thank Ian Hunter for invaluable comments and suggestions to an earlier version of this paper. I also received helpful comments at seminars at Department of Organization, Copenhagen Business School and The Whitlam Institute, Western Sydney University and from research group members Paul du Gay, Anne Roelsgaard Obling, Thomas Lopdrup-Hjorth and Mitchell Dean. Lastly, I thank the editors and reviewers at EJCPS for thoroughly constructive and clever engagement with the paper. 


\section{Introduction}

Recent decades have seen rising interest in John Dewey's political thought and his theory of democracy, often in the context of combating the presumed 'crisis of democracy', rising populism in Western political systems, or the triumph of neoliberalism. In many of these accounts, it is common to approach Dewey as a romantic democratic thinker, often with reference to his notion of creative or radical democracy (see for example Lake, 2017; Bernstein, 2010) or his ideal of democracy as a way of life (Honneth, 1998). Dewey has also been connected with post-Habermasian notions of the public sphere as a space of reflexivity and deliberation (as in Caspary, 2008; Zhao, 2014), and his understanding of democracy is taken as the ideal model for the development of accounts of public involvement in politics (Marres, 2007; Latour, 2007; Harman, 2007). Thus, while an understanding of publicness as a collective dynamic by which citizens come together and act politically is well represented in contemporary receptions of Dewey's political thinking, the institutional conditions and formal structures of the public in his thought are rarely discussed.

In this paper, I present a reading of Dewey's political thinking that presents him as a theorist of office and political representation. This is a reading that emphasises how Dewey did not only argue that a public must be secured and supported by state institutions, but more radically that the public is the state (Dewey 1927, p. 35). The state comes into being, Dewey argued, when concerted citizens come together in order to regulate and manage the unintended consequences of private associations and group behaviour. They organise this public by selecting representatives, the public officials that constitute the government. To argue that the public is the state is also to say that is only meaningful to think of a public in practical terms; that is, in terms of the particular public offices that constitute the state and represent the public interest. From this perspective, the public should not be understood as an indeterminable 'sphere' or a 'voice' but rather in terms of the concrete situations in which people act in their 
official or representative character rather than as private persons, as well as the institutions and systems that secure and makes such situations and acts possible.

As is evident in Dewey's seldom-read paper on Hobbes (1918), this emphasis on public office draws Dewey surprisingly close to a Hobbesian notion of representation and thereby to the tradition of office-based thinking of which Hobbes was part. Besides Hobbes, the 'ethics of office' tradition includes classic political philosophers such as Cicero (1991/44BC) and Pufendorf (1934) and has been continued in more recent sociological and historical accounts and discussions of public office-holding (Weber 1917, 1919, 1922; Hennis, 2009; Condren, 2006; du Gay, 2008; Strathern, 2017; see also the recent special section on 'Office' in this journal: du Gay, 2017; Hunter, 2017; Dean, 2017). What holds this research tradition together is a practical understanding of offices as bundles of duties and virtues inscribed in the particular roles that govern the conduct of individuals, as well as an understanding of the ethics of such offices as characterised by being distinct from the personal morality of those occupying them. Moreover, those dedicated to the study of office often share a representative understanding of politics founded on a perception of rulership as an entrusted office (see Hennis, 2009).

As is well-known, Dewey was rather suspicious of historical authority, and in alignment with pragmatism's turn to experience he warned us consistently about the abstractions of political philosophy and, in particular, of state-theory: "the moment we utter the words "The State" a score of intellectual ghosts rise to obscure our vision' (1927, p. 8). Thus, in line with a new and modernist empiricism in political analysis at the turn of the century, Dewey's turn to officebased thinking should be explained not with the intention of revitalising the thoughts of earlier political philosophers, but rather in connection with his engagement with the political challenges of his own time. Although Dewey had developed many of his political ideas in his earlier years (see Westbrook, 1991; Rakow, 2017) his turn to Hobbes in 1918 must be understood in close relation to his support to the American intervention in World War I - and 
to what has been described as '[t]he Hobbesian moment in American intellectual history' (Diggins, 1994, p. 358), in reference to the realisation by many American thinkers at the time that the sanction of force was vital for government to exert authority. Likewise, it is impossible to read Dewey's major work on political philosophy, The Public and its Problems (1927), without connecting its content to the intellectual climate of post World War I in America, where democratic values and ideals where heavily debated. More concretely, the book was a direct response to and engagement with the popular journalist and political commentator Walter Lippmann and his extensive critique of the American public, press and democracy (Lippmann, $1922,1925)$.

In the first part of this paper, I explore Dewey's (1918) debt to Thomas Hobbes, after which I turn to his underexplored conception of public office, as presented partly in his China lectures (1919-20/1973) but predominantly in the first part of The Public and its Problem (1927). On this basis, I argue that to understand Dewey's political theory, it is necessary to attend to his notion of the state as an organised public governed by public officers representing the public interest. ${ }^{1}$ Importantly, it is this office-based conception of representation that forms Dewey's understanding of democracy, where public office is extended to the citizen, both as a voter who has a duty to vote not as a private person but as a representative of public interest, and as a concerned citizen who engages with others in inquiries of fact and values in order to represent the public interest and regulate the indirect consequences of group behaviour via political

\footnotetext{
${ }^{1}$ Dewey's understanding of public offices as representatives of public interests differs in some respects from other dominant understandings of office. Most notably, perhaps, Max Weber understands an office to be the bearer of duties that define a particular sphere or way of life. The persona of the scientist, the politician, or the bureaucrat, for instance, is that which is cultivated within this sphere of life in accordance with its specific ends (pursuit of knowledge, competition for power, efficiency of administration, etc.). As such, there is not necessarily a 'general' public interest represented in these different offices. As Max Weber (1917) argues, life can be rationalized in different ways and for different purposes, and the different spheres of life are like 'warring gods'.
} 
participation and action. From this perspective, a democracy must be judged by the extent to which it is able to secure its public officers' functions, character, and conduct - including those of its citizens - rather than on, for instance, ideas of freedom of speech or public will.

\section{Public authority and offices of sovereignty: Dewey on Hobbes}

It is in the rarely cited paper 'The Motivation of Hobbes's Political Philosophy' from 1918 that Dewey's debts to Thomas Hobbes become particularly clear; indeed, central themes from Dewey's political philosophy become intelligible through his reading of Hobbes. In one of the few acknowledgments of this Hobbesian debt, Dewey has been said to offer 'a number of resources for infusing a democratic spirit into Hobbes's constructivism' (Brown, 2009, p. 135). As noted, Dewey's reliance on and tribute to Hobbes cannot be understood without a view to historical circumstance, and it is necessary to keep in mind that Dewey's paper on Hobbes was written concurrently with his development of an argument for the adequate and intelligent use of force as a defence of the American intervention in World War I (see Dewey, 1916b, 1919). However, Dewey's reading of Hobbes's political philosophy does not only signal his (at the time) realist attitude regarding the use of force as an instrument for social and political organisation. It can also serve as an introduction to his theory of the state, his rejection of absolutism, the relation between theology and science, freedom and authority, the public and the private, and - perhaps most importantly - the idea of public office, as this is later unfolded not least in The Public and its Problems (1927).

Dewey (1918) argued that Hobbes had been subjected to a 'temporal displacement' (p. 8) and that only by placing Hobbes's political philosophy in its own historical context would it be possible to understand that his theory of sovereignty - for which Hobbes was also criticised in Dewey's time - was closely connected to a historical conflict between church and state. More specifically, it was not Hobbes's idea of a supreme authority that led to the dispute - such an authority was claimed by most during the period at which Hobbes wrote - but rather his 
insistence on a secular basis for this authority. Dewey also noticed that Hobbes' critique of the rule of the church was primarily a critique of the private character of this rule; ecclesiastic interest was 'the source of divided allegiance and of the assumption of a right of private judgment over against a public law of right and wrong' (p. 30). In this sense, Dewey maintained, the conflict between civil and ecclesiastic power was, to Hobbes, essentially a conflict between the public and the private:

We fail to get the full force of Hobbes's conception of sovereignty until we see that to Hobbes the logical alternative is setting up the private opinions of individuals and groups of individuals as the rule of public acts - a method whose logical inconsistency has division and war for its practical counterpart (p. 24).

Thus, when Hobbes insisted on absolving the sovereign from all laws, even the moral ones, it should be understood as a critique of the actual conditions of the common law at the time; a law that functioned more, Dewey commented, as a private 'lawyer's law' (p. 18) than as publicly instituted legislation. As for the existing practices of moral law, these were - because of their private character - no more than 'an enlightened hedonism' (p. 18). Dewey, who was himself a firm believer in scientific inquiry, identified Hobbes as a promoter of science (or 'demonstrative knowledge') rather than private opinion as the foundation of politics: 'Scientific demonstration is the sole alternative to the continuation of the troubled regime of opinion' ( $\mathrm{p}$. 23).

According to Dewey (1918), Hobbes' distinction between publicly instituted authority (based on science) and the hedonism of private opinion is the key to understanding the Hobbesian theory of the state. To Hobbes, Dewey argued, the purpose of the state - and that to which its authority is dependent - was the common good. Moral law, then, was 'equivalent to the counsels or precepts of prudence, that is to say, of judgment as to the proper means for attaining 
the end of a future enduring happiness' (p. 26). So although Dewey criticised Hobbes for his 'exclusive self-interest doctrine' (p. 11), he argued rather creatively that Hobbes should be understood as a social consequentialist not unlike Bentham. It was on the basis of this 'utilitarian reasoning' that Hobbes argued for obedience to the commands of a protective power, because even arbitrary acts by the sovereign are better for the common good than private judgments based on immediate passions and appetites. ${ }^{2}$ However, this left Hobbes, Dewey stated, with a paradox. On the one hand, he maintained that politics is to be based on science, but on the other he was left with the potentially arbitrary rule of his sovereign. Hobbes' method of dealing with this paradox, Dewey suggested, takes us to 'his conception of the aim and purpose, or “offices” of sovereignty' (p. 25). In Hobbes' description of these offices - which include for instance equality of taxes, public charity, or equality of justice - the limits of the sovereign's power become evident. One such limit is to be found in the fact that allegiance to the state is not to be taken as a positive command but as a moral obligation. Secondly, the power of the sovereign is solely directed against the acts of the individual: "it cannot affect, and (except through education) is not indented to affect inner inclinations or desires, but only acts - which are external' (Dewey, 1918, p. 29). Thirdly, not all acts can be commanded. Thus, we find in these limits the Hobbesian reconciliation of freedom and authority. Dewey here quotes the English translation of De Cive, where Hobbes argued that:

\footnotetext{
${ }^{2}$ Understanding Hobbes as a utilitarian is indeed a creative reading. Most scholars would argue that, for Hobbes, social peace is the end of sovereignty rather than the common good. Thus, Hobbes does not use a utilitarian calculus to justify civil sovereignty, not least because if he did then agents other than the sovereign could claim to judge whether the sovereign was acting on utilitarian grounds. Moreover, it is contestable to claim that Hobbes believed sovereignty to be based in science, although Hobbes did understand his own work as 'political science'. Therefore, it is important to approach Dewey's reading of Hobbes as a way into understanding Dewey rather than as a faithful reading of Hobbes.
} 
It is necessary that there be infinite cases which are neither commanded nor prohibited, but every man may either do or not do them as list himself.... As water, inclosed on all hands with banks, stands still and corrupts; having no bounds it spreads too largely, and the more passages it finds the more freely it takes its current; so subjects, if they might do noting without the commands of the law, would grow dull and unwieldy; if all, they would be dispersed; and the more that is left undetermined by the laws, the more liberty they enjoy. Both extremes are faulty; for laws were not indented to take away, but to direct men's actions; even as nature ordained the banks not to stay, but to guide the course of the stream (Hobbes, 1651, p. 178).

The themes of Dewey's reading of Hobbes - the distinction between public and private authority, the understanding of public office, the inseparability of authority and freedom, the purpose of the state understood as the common good, as well as the 'scientific' basis of politics - are all important themes for Dewey's authorship. While these are themes that are most consistently developed in The Public and its Problems (1927), Dewey did treat many of them in various other texts leading up to this work. A particularly interesting place to turn here is to Dewey's Lectures in China, 1919-20 (Dewey, 1973).

\section{The Problem of Government as a Problem of Office}

Dewey's China lectures stands out as a relatively coherent contribution to political and social philosophy delivered particularly to a Chinese audience during a longer stay in Asia between 1919 and $1921^{3}$ (see Pappas, 2017). For our purposes the lecture on Government, where Dewey turned to Machiavelli, Hobbes and Spinoza to represent his view on the political organization of the state (Dewey, 1973, p. 133), is of particular importance as one of the few places, beside

\footnotetext{
${ }^{3}$ John Dewey and his wife stayed in China for more than two years between 2019 and 2021. Dewey's lectures were originally delivered in English, but for long they were only published in Chinese. In 1973, they were translated back from Chinese into English (Dewey, 1973).
} 
the Hobbes paper (1918), where Dewey attended to and developed his notion of office, which was to become so vital for the development of his theory of the public (1927). The lecture on government starts by reference to the fact that governing is always done by actual persons. It is, Dewey suggested, the conduct of these persons that constitutes what can be defined as 'the problem of government'. This is, namely, 'the problem of making government an effective means of accomplishing the legitimate ends of the state and of forestalling the tendency to subvert it to the ambitions, desires, and selfish ends of the individuals who compose it' (Dewey 1973, p. 134). The most important task, then, in relation to the organisation of the state is to ensure that the conduct of the public officials that constitute government is in accordance with the duties of their offices and not with any private goals or desires. Thus, on the difficult question of governmental use of force, Dewey says the following to his Chinese audience:

The problem of government is a thorny one. Realization of the ends of government requires resort to force - else government may not be able to repel invasion from without or enforce its laws within. But the power rests in the hands of the officials who make up the government, and a major problem is to insure that these officials use the power of government in the interest of the public welfare rather than to their own selfish advantage. This is a practical problem, not just a bookish one. Students of government in the last three centuries have advocated responsible, representative constitutional government as the most effective safeguard against that malfeasance in office which abuses power and works against public welfare (p. 134).

To Dewey, then, the question is not one for or against the use of force, but rather for the establishment of a governing system ('a responsible, representative constitutional government') in which public officials are trained to use their powers (and execute force) in the interest of public welfare. Therefore, Dewey contended, the problem of government is also 
a question of human nature and of the basic 'need of restraints to prevent good men becoming evil' (p. 135). By suggesting that these restraints are to be dealt with through the allocation of offices, Dewey echoes his earlier discussion of Hobbes' offices of sovereignty as instituting limits on the sovereign's power, and as that which allows for the reconciliation of freedom and authority (Dewey, 1918). It is equally the attitude towards such restrictions on government and therefore essentially the question of office - that according to Dewey separates a German Hegelian absolutist tradition of political thought from an early modern British tradition (see Dewey, 1973, p. 136-137). In this way, the concept of office becomes an important piece in Dewey's fight against absolutism, and, as we shall see in the following, the essential component of Dewey's development of a theory of the public.

\section{The Public Organised as a State}

In The Public and its Problems (1927), Dewey argued that '[t]he state is the organization of the public effected through officials for the protection of the interests shared by its members' (p. 33). In line with his empiricism, he quickly added that any further definition of the state is an empirical matter: 'what the public may be, what officials are, how adequately they perform their functions, are things we have to go to history to discover' (p. 33). Therefore, there is no general definition of the good state or the public interest, and there are no a priori rules by which a good state can be brought about, as dominant 'metaphysical monistic philosophies of politics' (p. 38) tend to claim. However, we do have the possibility of empirically judging 'how good' a particular state is according to two criteria. First, we can interrogate 'the degree of organization of the public' and, second, 'the degree in which its officers are so constituted as to perform their function of caring for public interest' (p. 33). So, in alignment with the China lectures, Dewey draws our attention to office-holding, the conduct of officials, and the formal constitution, organisation and reach of such public offices as the themes that determine the 
character of the state and the government thereof. Now, however, he specifically defines the state as an organised public governed by public officers.

The distinction between the public and private is at the core of Dewey's understanding of public office and the functioning (and character) of the state:

The line between private and public is to be drawn on the basis of the extent and scope of the consequences of acts which are so important as to need control, whether by inhibition or by promotion. We distinguish private and public buildings, private and public schools, private paths and public highways, private assets and public funds, private persons and public officials. It is our thesis that in this distinction we find the key to the nature and office of the state (p. 15).

As the quotation indicates, Dewey distinguished - in line, of course, with his pragmatist attitude - between the private and the public in terms of the reach of the consequences of actions. The source of the public is 'the perception of consequences which are projected in important ways beyond the persons and associations directly concerned with them' (p. 39). Thus, Dewey suggested that a public comes into existence when concerted people come together to regulate the indirect consequences of private association and group-action. The public in itself is 'unorganized and formless' (p. 67), but when operating through selected representative officers who have been granted special powers it becomes a state; 'association adds to itself political organization' (p. 35). The state, then, is the organisation of a public in representative offices and special agencies that are able to regulate the "widely distributed consequences, which, when they are perceived, create a common interest' (p. 54).

Importantly then, Dewey's organised public is not an abstract or romantic ideal about a public sphere, or a public voice or opinion, but rather it is a concept that includes equally the specific organisation of state institutions and the officially appointed representative public officers that 
work to secure the public interest and publics understood as groups of people that come together to inquire into, define, resolve or govern diverse types of problems with unwanted consequences. Hereby private persons becomes public citizens who act to represent the public interest.

A few things should be noted about this understanding of the public and the public interest. First, what constitutes the public interest is not necessarily that which is socially preferable. Dewey (1927) made clear that his idea of a public is grounded solely in the distinction between the public and private and not in the distinction between the social and the individual, as private acts can easily be social and contribute to the "welfare of the community or affect its status and prospects' (p. 13), while public acts are not necessarily 'socially useful', as the case of war illustrates. Here, we must again recall Dewey's defence of the American participation in World War I in which he differentiated irrational violence from a prudent use of force (see for example Dewey, 1916b, 1919).

Second, focusing on the perception of widely distributed consequences as the main distinction between the private and the public (and the state), Dewey (1927) argued against what he determined as 'causal agency theories' (p. 66) of state formation and development, criticizing here both the Hobbes and Rousseau camps for taking "will" to be the causal force which generates the state' (p. 53) - although, as we have seen, he also attributed to Hobbes a widespread consequentialism. Through the focus instead on 'the lasting, extensive and serious consequences of associated activity' (p. 67) as the never 'sharp and fast' (p. 43) demarcating line between the public and private, extension and reach rather than intentions and social contract theory become central in Dewey's historical account of state formation. 


\section{Public officers}

As we have seen, Dewey had a thoroughly representative understanding of the public and the state. The public consists of the specific organisations, institutions, and - not least - people who act as representatives for the public interest: The 'public is organized and made effective by means of representatives who as guardians of custom, as legislators, as executives, judges, etc. care for its special interests by methods intended to regulate the conjoint actions of individuals and groups' (Dewey, 1927, p. 35). This leads us to Dewey's understanding of the public officer.

When the public or state is involved in making social arrangements like passing laws, enforcing a contract, conferring a franchise, it still acts through concrete persons. The persons are now officers, representatives of a public or shared interest. The difference is an important one. But it is not a difference between single human beings and a collective impersonal will. It is between persons in their private and in their official or representative character. The quality presented is not authorship but authority, the authority of recognized consequences to control the behavior which generates and averts extensive and enduring results of weal and woe. Officials are indeed public agents, but agents in the sense of factors doing business of others in securing and obviating consequences that concern them (1927, p. 19).

The existence of public officers, Dewey (p. 27) argued, is the obvious external mark of the organisation of a public and hence of the state. But the officers (and their offices) are more than just an external mark - they are what essentially constitute the state and the public, as neither have any abstract existence beyond the personae that act on their behalf. It is therefore also the character and conduct of the public officials that allow us to judge the goodness of a state: 'The state is as its officials are' (Dewey, p. 69). So in alignment with the Chinese lectures' (1973) definition of the problem of government as a problem of office, Dewey argued that for a state 
to be good, public officers such as judges, executives, and administrators must be trained to and selected for their capacity to serve the public interest.

Importantly, and as a trademark of his pragmatist attitude, Dewey understood the definition of the officer as 'founded on the exercise of a function, not on any inherent essence or structural nature' (p. 77). Therefore, 'officer' should be taken to refer to a functional understanding of office as being representative of interest, and he added: 'In households, for example, there have usually been rule and "heads"; the parents, for most purposes the father, have been officers of the family interest' (p. 66). It is here worth noting that Dewey therefore had an explicitly normative understanding of the public officer as someone who by functional definition represents the public interest. However, this does not prevent actual officers from failing to live up to the offices they are bestowed. History shows, Dewey argued, that every officer of the public has a 'dual capacity'. Their powers might be used to serve their private interest, thereby making government corrupt and arbitrary. On the other hand, Dewey maintained, 'occupancy of office may enlarge a man's views and stimulate his social interest so that he exhibits as a statesman traits foreign to his private life' (p. 68). Dewey's critique of American democracy presented in the section The Eclipse of the Public in the second half of The Public and its Problems therefore also largely pertains to the problem of American democracy (and the American public) as a problem of persons acting in private rather than public roles and capacities. This distinction between public and private roles of the citizen is also vital to understanding Dewey's well-known controversy with Walter Lippmann.

\section{An office-based view of the Dewey-Lippmann democracy debate}

As indicated, Dewey's discussions of democracy and public office in The Public and its Problems cannot be properly understood without reference to the intensive post-WWI intellectual discussions in America on democratic failures and mass culture, supported by a growing sense that democracy was unable to deal with the complexities of modern life. Such 
anti-democratic spirits were not least to be found in Walter Lippmann's Public Opinion (1922) and The Phantom Public (1925), to which Dewey's book was partly a direct response. Lippmann criticised what he understood to be democratic theory's naïve assumption of an 'omnicompetent' citizen capable of making rational judgments when presented with 'facts'. Such theory, Lippmann argued, neglected our human inclination towards producing stereotypes and the press's tendency to distort information. It is widely acknowledged that Dewey and Lippmann shared a critical stance regarding the American public and press and to a large extent - on the challenges of democracy. Thus, in Dewey's 1925 review of The Phantom Public, he delivered a reading of Lippmann's project that was both constructive and supportive, although he did suggest that Lippman's critique was directed at a straw man: Lippmann's phantom was democratic theory - and not democracy in practice (Dewey 1925: p. 217 - see also Dewey 1927, p. 158 for Dewey’s support to Lippmann). In what has since been termed the Dewey-Lippmann debate (Carey, 1989), it is, however, Dewey's and Lippman's different solutions to the challenges of democracy that has been highlighted. Dewey is here represented as a democratic optimist defending the democratic ideal, while Lippmann is portrayed as remaining a pessimist, believing that democracy systematically produced mediocrity and therefore arguing for the necessary control of the knowledge streams by a political elite of intellectuals and experts. What is rarely acknowledged in the discussion of this controversy is how the differences between Lippmann and Dewey might be partly explicable with reference to their very different understandings of public offices and personae and the distinction between the public and private.

Lippman's lack of faith in public office is most evident in Public Opinion (1922). He is here widely cited for the quote that 'there are at least two distinct selves, the public and regal self, the private and human' (p. 3). So although Lippmann was acknowledging a distinction between the person in public and in private roles, his use of the notion 'human' implies that he 
understood only the private person as 'the human' (that is, as the 'real' self), whereas he described the various public roles and personae of any individual as 'symbolic personalities' (p. 5) or even 'façades' (p. 4). Great men, Lippmann argued, are always only displayed to the public as 'fictitious personalities' (p. 3), and, likewise, royal personages should be understood as 'constructed personalities' (p. 3). Thus, Lippmann maintained that the portraits painted of a public persona are 'not of an actual human being' (p. 4). This understanding of the private self as the 'real' self is of course in strict opposition to the office-based position of John Dewey. Not only did Dewey (1927, p. 15) confer just as much 'reality' to any public office one might hold as to more private roles, he also normatively held that a life without such public personae and representational functions was a deprived life.

Rooted in Lippmann's dismissal of the 'realness' of the public persona, I believe that we find an important but often hidden or unnoticed cause for the Lippmann-Dewey controversy. Taking 'the private self' of individuals as the point of departure, Lippmann considered only individuals in their private roles and the grouping together of such individuals only as masses and not as publics in any Deweyian sense. Thus, it was by reasoning that 'out of the private notions of any group no common idea emerges by itself' (1922, p. 125) that Lippmann argued for the need for a machinery of elite control of the democratic processes. He further stated that:

As the public appeal becomes more and more all things to all men, as the emotion is stirred while the meaning is dispersed, their very private meanings are given a universal application. Whatever you want badly is the Rights of Humanity. For the phrase, ever more vacant, capable of meaning almost anything (p. 117).

In this way, then, the 'public opinion' of Lippmann's book title is in reality only a congeries of private opinions. This critique of 'public opinion' and its randomness, sensationalism and 
private character is echoed in Lippmann's The Phantom Public (1925) where he describes the public as follows:

We must assume that a public is inexpert in its curiosity, intermittent, that it discerns only gross distinctions, is slow to be aroused and quickly diverted; that, since it acts by aligning itself, it personalizes whatever it considers, and is interested only when events have been melodramatized as a conflict (p. 55).

Dewey - as we have seen - agreed in the critique of private opinion, of the masses, and of the private character of a rights-based perspective on democracy. And much like Lippmann, he also expressed concerns about a modern industrialised society that had largely eroded traditional forms of life and community. This had, according to Dewey, resulted in a society where the public could not sufficiently recognise and organise itself as a public (through public officers and intelligent inquiry) and hence, could not take effective action. Therefore, Dewey insisted, the random and 'casually formed' opinions that Lippmann described as public opinion can 'only be public by name' (Dewey, 1927).

So while Dewey largely shared Lippmann's definition of the problem, the office-based approach allowed him to propose another path for representative democracy. To him, the democratic failure was the failure of the state to realise the function of citizens as representatives of public interest. As noted, Dewey (1927) argued that the 'goodness' of a state can be measured by the degree to which its public officers, including its citizens, are 'so constituted as to perform their function of caring for public interest' (p. 33). This implies that state institutions must make sure that public offices are organised in ways that ensure the domination of the officer's public weal, their ability and desire to act as representatives of the public interest, as well as to minimize potential conflicts with the officers' other (private) desires. For a state to be good, then, public officers such as judges, executives, and 
administrators must be selected for their capacity to serve the public interest. And in democracies, this demand is extended to the citizens, who must be trained to engage in democratic processes, not as private individuals with private opinions but in the role of public officers attending to consequences that reach beyond their own lives. Such roles are not constructs, façades, or symbols covering an individual's 'real self', as Lippmann would have it, but rather the actual function and duty of citizens in democracies, which they must be trained to and supported in fulfilling. Thus, it is this vital difference between acting as a private person or carrying out the duties of a public office that forms Dewey's alternative understanding of representative democracy and, importantly, his understanding of the citizen's role in democratic societies.

\section{Representative democracy and the citizen as officer}

Dewey was critical towards both liberal and communitarian understandings of representative democracy. On the one hand, he was critical towards the liberals' understanding of the individual's natural capacity to participate in public matters and to represent public interest and towards their faith in elections and majority rule as sufficient to support the structures of representative democracy and elected representatives' responsibilities (see for instance Dewey 2016a, p. 106-108). On the other hand, he was equally critical towards communitarian conceptions of the democratic state, because while liberalism led to the isolation of individuals, an organic understanding of the state suppressed individuality (see for instance Dewey 1916a, p. 108-112). Therefore, as Brown notes, 'Rather than merely debunking collectivist and liberal conceptions of political representation, Dewey shows how representation in a democracy depends on state institutions that facilitate civic engagement in local settings' (Brown 2009, p. 137). And more specifically, I believe, it was the organisation of the state into public offices and the institutions that form, secure and support such offices - as well as the extension of public office to include citizens as voters and engaged public participants - that forms the basis 
of Dewey's understanding of representative democracy and made it possible for Dewey to go beyond both liberalism and communitarianism.

Thus, to Dewey, an essential difference between a democracy and other forms of government (monarchy or aristocracy for instance) is the extension of representative functions to the citizen. In a democracy, the citizen is a public officer by functional definition. This means that as a voter, for instance, the citizen should be understood as an officer of the public with the binary capacity of voting as either a representative of the public interest or as a private person wishing to ensure, for instance, personal profit. In the second instance, he fails 'in effort to represent the interest entrusted him' (p. 76) - thus, he fails to live up to his entrusted office. Likewise, Dewey highlighted the representational function of the citizen as an engaged and concerted participant in various types of public and political engagements, inquiries and problem-solving connected to the perhaps various publics (related to different types of problems or unwanted consequences of action) to which he or she belongs and becomes a spokesperson.

Thus, a well-functioning representative democracy is one that is organised in ways that help the public officers - that is, both the officers deployed by the state and the citizens as officers - to ensure 'the domination by their public weal by their other desires' (p. 76):

When the public adopts special measures to see to it that this conflict is minimized and that the representative function overrides the private one, political institutions are termed representative (p. 77) .

Dewey was not willingly going into much detail about the specific organisation or administrative procedures (such as bureaucracy) that he was here clearly hinting at with the notion of 'special measures'. In line with his comprehensive life-long contribution to educational thinking and practice, Dewey was more eager to address the training and education that is needed in order for individuals to adopt a democratic attitude and to act in the public 
interest. All habits, Dewey argued in Human Nature and Conduct (1922), are acquired, and it is through acquiring habits that we learn how to act in specific situations: ' ... all distinctively human action has to be learned, and the very heart, blood and sinews of learning is creation of habitudes' (1927, p. 160). Dewey is well-known for his ideal of learning by doing - or more correctly 'learning from experience' (Dewey 1916a, p. 140) - which means that learning and habituation take place through continual engagement in established modes of behaviour and practices of action and inquiry. This also goes for the skills, routines, and competences that are needed to obtain any public office, where the appropriate conduct and virtues are to be habituated and embodied through participation in representative activities (in schools, political organisation, social life and so on). It should be noted that Dewey did not understand the habituation, training or practicing of representative functions as merely a troublesome duty for the citizen in the democratic society. On the contrary, as earlier noted, Dewey maintained that to act in an official capacity can 'enlarge a man's views and stimulate his social interest' (1927, p. 68) and it is clear that, for Dewey, a life without a public office of some sort is a deprived life: "It is not without significance that etymologically "private" is defined in opposition to “official," a private person being one deprived of public position' (p. 15).

As earlier noted, this office-based position underscores Dewey's attempt to reconcile freedom and authority. Here it becomes evident that not only is office a way of constraining the power of the sovereign, it is also a way of achieving a kind of freedom for the officeholder. Arguing against liberalism's idea of freedom as the absence of constraint on the individual and his/her ability to act or pursue chosen goals, Dewey insisted that individual rights have little to do with freedom - or with democracy, for that matter. Instead, Dewey viewed individual rights as a largely practical (and negative) matter. For instance, he understood freedom of speech - or what he described as 'the so-called right to private judgment' (p. 51) - as a 'somewhat precarious rationalization of the moderate amount of toleration which has come into being' (p. 
51). That is, we have learned from negative consequences, not from positive social benefits, that we are better off tolerating each other's private beliefs and judgments and, he added, 'phenomena as the Ku Klux and legislative activity to regulate science show that the belief in liberty of thought is still superficial' (p. 51). Thus, to Dewey, freedom in a democracy is not to be found in individual rights and private liberties, although these must be tolerated, but rather in the possibility of holding a public position and to act as a representative of the public interest in democratic processes. In this way, it is not only the character and goodness of a state but also the freedom of its citizens and their quality of life that are dependent on securing public office and engagement.

\section{Concluding remarks}

In The Promise of Pragmatism, Diggins (1994) argues that Dewey's political writings consistently returned to two major problems of political theory, which are

'... a liberal legacy that conceives the individual as self-sufficient and asserting his natural rights against the encroachments of government, and a modernist temperament that judges individuals ill prepared for the demands of responsible politics and rational decision-making (p. 300).

In this paper, I have argued that Dewey finds the solution to these problems in an office-based approach to politics and especially by approaching the representative functions of citizens in a democracy in terms of public office.

As implied in the introduction to this paper, Dewey's turn to office connects him (although perhaps not willingly) to an 'ethics of office' research tradition. Within this tradition, the idea of the citizen as an officer in the democratic society is not unheard-of. In the political scientist and Weber scholar Wilhelm Hennis' reflection on 'the idea of office and the concept of democracy' in his Politics as a Practical Science (2009, Chapter 2), for instance, he suggests 
that ' $[t]$ he central concept of representative democracy is not popular sovereignty, nor popular will, but administrative office' (p. 30). Moreover, Hennis argues that in a representative democracy, in opposition to a plebiscitary one, the community 'understands its power to be a duty, an entrusted office, not a voluntarist competence, as a decisionistic claim' (p. 29). Thus, in a representative democracy the citizen understands his/her function to be a public and representational one.

To this should be added other contemporary attempts to discuss citizens as representatives often in connection with contemporary ideals of user-involvement and public engagements (Stephan 2004; Warren 2008) - and even attempts to develop more coherent theories of democratic citizenship as office-based, such as Eric Beerbohm's In Our Name: The Ethics of Democracy (2012). Here Beerbohm offers a number of moral principles for the office of the citizen and defines participatory responsibilities in a democracy as ethical practices for which citizens are morally liable - even when politics is potentially unjust.

Dewey delivers a very distinctive pragmatist contribution to these discussions. This is a contribution that creatively links office as a representative function to the governing of indirect and unwanted consequences of group behavior and association - whether such offices are officially appointed by state institutions or occur as a result of concerned citizens coming together to inquire and problem-solve in order to represent public interest. And it is a contribution that avoids recourse to universal moral principles but instead draws our attention to the constant need to secure the situation-based development of citizenship as public office and secure the systems and institutions that can support private persons in becoming public citizens. But it is also a contribution that is rarely appreciated in the dominant reception of Dewey's political philosophy, where the perhaps most formative contemporary work, Westbrook's John Dewey and American Democracy (1991), for instance, does not mention public office with a single word. Based on the reading primarily of three distinctive texts by 
Dewey $(1919,1919-20 / 1973,1927)$, this paper has started to outline the contours of Dewey as an office-based thinker. This reading is important not only because Dewey's understanding of public office and, not least, the office of the citizen in democratic societies, is a valuable contribution to political philosophy and democratic theory in its own right but also because the office-based perspective can cast new light on other aspects of Dewey's authorship, not least his well-known definitions of democracy as 'associated living' (1916a, 1927) and as 'a way of life' (1937). When Dewey in some of his later works writes, for instance, that democracy must 'become part of the bone and blood of the people in daily conduct of its life' and that 'unless democratic habits of thought and action are part of the fiber of a people, political democracy is insecure' (Dewey, 1937, p. 457), these contentions can be understood from this office-based perspective. Citizens must be trained to think and act in public and representative, not private and personal, ways in order to live up to their democratic duties of office. As Dewey had already argued in Democracy and Education (1916a, p. 101), 'a government resting upon popular suffrage cannot be successful unless those who elect and who obey their governors are educated.' More specifically they must be educated, trained and habituated to engage in inquiries of fact and values and to think and act as representatives of the public interest. And by suggesting that being a citizen in a democratic society is an entrusted office, Dewey reminds us not only of the importance to have systems in place to train, habituate and evaluate politicians', administrative staff's, or appointed officials' ability to live up to their obligations and act in their capacity as public officers, but also of the importance of having systems in place to ensure citizens' ability to do so.

Thus, if Dewey's political writings can be said to deliver a comment to our current 'crisis of democracy', not least in the aftermath of Trump and Brexit, it is - according to this argument - not in any romantic idea of plebiscitary forms of democracy or in abstract notions of public will or public voice, but rather in this understanding of representative democracy as 
intrinsically linked with the concept of public office: not least with the idea of the citizen as a public officer who must be trained and supported to engage in political matters and public inquiries in representative rather than private ways. This is, perhaps, Dewey's main contribution to the discussion of the possible eclipse of the public in modern society. With this Deweyan perspective we need not dismiss the idea of a 'public will' or publicness, but rather contend that such concepts are only meaningful in the concrete; in terms of the voter who votes not as a private person to secure personal profit, but as a representative of public interest; in terms of the concerted citizen who joins others to form a public by inquiring into, reacting to or somehow governing or regulating diverse types of indirect consequences of private association and group action (being it climate change or more local/communal problems); in terms of the more traditional public office-holders and civil servants appointed by the state to take on invaluable official positions and roles; or in terms of the state institutions and

educational systems that create, support, evaluate and secure the very possibility of public inquiry and office-holding.

\section{References}

Beerbohm, E. (2012). In Our Name: The Ethics of Democracy, Princeton: Princeton University Press.

Bernstein, R. J. (2010). Dewey's vision of radical democracy. In Molly Cochran (Ed.), The Cambridge Companion to Dewey. Cambridge, UK: Cambridge University Press.

Brown, M. B. (2009). Science in Democracy: Expertise, Institutions and Representation. Boston: The MIT Press.

Carey, J. (1989). Communication as Culture. New York: Routledge. 
Caspary, W. R. (2008). On Dewey, Habermas and Deliberative Democracy. Journal of Public Deliberation, 4, 1, Article 10.

Cicero, M.T. (1991). On Duties (De Officiis). (Griffin, M.T, and Atkins, E.M., Trans.). New York: Cambridge.

Condren, C. (2006). Argument and Authority in Early Modern England. Cambridge, UK: Cambridge University Press.

Dean, M. (2017). Office and Agamben's genealogy of economy and government. European Journal of Cultural and Political Sociology, 4, 2, 200-222

Dewey, J. (1888/1969). The ethics of democracy. In J. A. Boydston (Ed.), John Dewey: Early essays and Leibniz's new essays. Carbondale, IL: Southern Illinois University Press.

Dewey, J. (1916a). Democracy and Education: An introduction to the philosophy of education. New York: The MacMillan Company

Dewey, J. (1916b). Force, Violence and Law. The New Republic, January 22, pp. 295-296.

Dewey, J. (1918/1975). The motivation of Hobbes's political philosophy. In R. Ross (Ed.), Thomas Hobbes in his Time. Minnesota: University of Minnesota Press.

Dewey, J. (1919). The Discrediting of Idealism. The New Republic, October 8, pp. 285-287.

Dewey, J. (1922). Human Nature and Conduct: An Introduction to Social Psychology. New York: Promentheus Books

Dewey, J. (1925). Practical Democracy, Review of The Phantom Public, by Walter Lippmann. In The Later Works, vol. 2, J.A. Boydston (Ed.). Carbondale and Edwardsville: Southern Illinois University Press. 
Dewey, J. (1927/1988). The Public and its Problems. Ohio: Ohio University Press.

Dewey, J. (1937). Democracy and Educational Administration. School and Society 45, 457467.

Dewey, J. (1973). John Dewey. Lectures in China, 1919-1920. R.W. Clopton \& Tsuin-Chen Ou (Eds. and translation), Honolulu: The University Press of Hawaii

Diggins, J. P. (1994). The Promise of Pragmatism: Modernism and the Crisis of Knowledge and Authority. Chicago and London: University of Chicago Press.

Du Gay, P. (2008). Max Weber and the Moral Economy of Office. Journal of Cultural Economy, 1, 2, 129-144.

Du Gay, P. (2017). Introduction: Office as a vocation. European Journal of Cultural and Political Sociology, 4, 2, 156-165

Harman, G. (2007). Bruno Latour: Reassembling the Political. London: Pluto Press.

Hennis, W. (2009). Politics as a Practical Science. (K. Tribe Trans.). Basingstoke: Palgrave Macmillan.

Hobbes, T. (1651). Leviathan. London: Printed for Andrew Crooke.

Hobbes, T. (1651/1983). Philosophical Rudiments Concerning Government and Society. English version of De Cive, H. Warrender (Ed.), Vol II.

Honneth, A. (1998). Democracy as Reflective Cooperation: John Dewey and the Theory of Democracy Today. Political Theory 26, 6, 763-783.

Hunter, I. (2017). Giorgio Agamben's genealogy of office. European Journal of Cultural and Political Sociology, 4, 2, 166-199. 
Latour, B. (2007). Turning Around Politics. A Note on Gerard de Vries' Paper. Social Studies of Science, 37, 5, 811-820.

Lippmann, W. (1922/2004). Public Opinion. New York: Dover Publications, Inc.

Lippmann, W. (1925/2017). The Phantom Public. London \& New York: Routledge.

Marres, N. (2007). The Issues Deserve More Credit: Pragmatist Contributions to the Study of Public Involvement. Social Studies of Science, 37, 5, 781-809.

Pappas, G. (2017). The Centrality of Dewey's Lectures in China to his Socio-Political Philosophy, Transactions of the Charles S. Peirce Society: A Quarterly Journal in American Philosophy, 53, 1, 7-28

Pufendorf, S. (1934). The law of nature and of nations in eight books. (C. H. Oldfather \& W. A. Oldfather, Trans. Vol. 2). Oxford: Clarendon Press.

Rakow L. F. (2017). Family Feud: Who's Still Fighting about Dewey and Lippmann? Javnost - The Public 25, 1-2, 75-82.

Stephan, M. (2004). Citizens as Representatives: Bridging the Democratic Theory Divides. Politics \& Policy, 32, 118-135.

Strathern, M. (2017). Afterword: the disappearing of an Office. In A. Lebner (Ed.), Redescribing Relations (pp. 209-220). Oxford: Berghahn.

Warren, M. (2008). Citizen representatives. In M. Warren \& H. Pearse (Eds.), Designing Deliberative Democracy: The British Columbia Citizens' Assembly. Cambridge: Cambridge University Press, pp. 50-69.

Weber, M. (1917/1989). Science as a Vocation. In P. Lassman \& I. Velody (Eds.), Max Weber's Science As A Vocation. London: Unwin, Hyman. 
Weber, M. (1919/1994). The profession and vocation of politics. In P. Lassman \& R. Speirs (Eds.), Weber: political writings. Cambridge: Cambridge University Press.

Weber, M. (1922/1978). Economy and Society. Berkeley: University of California Press.

Westbrook, R.B. (1991). John Dewey and American Democracy, Ithaca and London: Cornell University Press

Zhao, G. (2014). The Public and Its Problem: Dewey, Habermas, and Levinas. Journal of Educational Controversy, 8, 1, Article 6. 